\title{
Mineral Composition of Young Rabbiteye and Southern Highbush Blueberry Exposed to Salinity and Supplemental Calcium
}

\author{
Glenn C. Wright ${ }^{1}$ \\ Department of Horticultural Sciences, Texas A \& M University, College Station, TX 77843-2133 \\ Kim D. Patten ${ }^{2}$ \\ Texas A \& M University Agricultural Research and Extension Center, P.O. Drawer E, Overton, TX 75684 \\ Malcolm C. Drew ${ }^{3}$ \\ Department of Horticultural Sciences, Texas A \& M University, College Station, TX 77843-2133
}

Additional index words. mineral nutrition, salt stress

\begin{abstract}
Tifblue' and 'Brightwell' rabbiteye blueberry (Vaccinium ashei Reade) and 'Sharpblue' southern highbush blueberry (primarily $V$. corymbosum) were treated with 0,25 , and $100 \mathrm{~mm} \mathrm{Na}^{+}$as $\mathrm{Na}_{2} \mathrm{SO}_{4}$ or $\mathrm{NaCl}$, and $0,1,3$, and $10 \mathrm{~mm}$ supplemental $\mathrm{Ca}^{2+}$ in sand culture in the greenhouse. For rabbiteye plants salinized with $\mathrm{Na}_{2} \mathrm{SO}_{4}$, leaf $\mathrm{Na}^{+}$concentrations increased 54-fold and the percentage of total plant $\mathrm{Na}^{+}$found in the leaves increased from $9 \%$ to $63 \%$ with increasing external $\mathrm{Na}^{+}$. Calcium supplementation reduced the $\mathrm{Na}^{+}$concentrations in leaves by up to $20 \%$. Leaf $\mathrm{Ca}^{2+}$ concentrations increased with $\mathrm{Ca}^{2+}$ supplementation, but accounted for a decreasing percentage of the total $\mathrm{Ca}^{2+}$ found in the plant, since

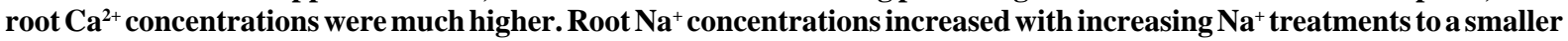
extent than in the leaves and were also reduced by $\mathrm{Ca}^{2+}$ supplements. Potassium concentrations in leaves and roots decreased with increasing $\mathrm{Na}^{+}$treatment levels, particularly in roots, where $\mathrm{K}^{+}$concentration was about half at $100 \mathrm{~mm}$ $\mathrm{Na}^{+}\left(\right.$as $\mathrm{Na}_{2} \mathrm{SO}_{4}$.) Leaf $\mathrm{Na}^{+}$concentrations were up to two times greater when $\mathrm{Na}^{+}$was supplied as $\mathrm{NaCl}$ compared to $\mathrm{Na}_{2} \mathrm{SO}_{4}$. For plants salinized with $\mathrm{NaCl}$, leaf $\mathrm{Na}^{+}$levels increased to $1.1 \%$ and did not decrease when supplemental $\mathrm{Ca}^{2+}$ was applied. Leaf $\mathrm{Cl}^{-}$concentrations also increased greatly with $\mathrm{NaCl}$, reaching $>1.0 \%$ (dry weight basis.). $\mathrm{Root}^{-}$ concentrations also increased with increasing salinity and were not affected by $\mathrm{Ca}^{2+}$ supplements. $\mathrm{Ca}^{2+}$ supplementation led only to a greater $\mathrm{Ca}^{2+}$ concentration in leaves and roots, but this did not alter $\mathrm{Na}^{+}$concentrations. Nutrient concentrations in 'Sharpblue' leaves, stems, and roots were greater than those of the rabbiteye cultivars, but were influenced by salinity and $\mathrm{Ca}^{2+}$ in essentially the same way. Excess $\mathrm{Na}^{+}, \mathrm{Cl}^{-}$, or both, together with lowered $\mathrm{K}^{+}$, were likely the cause of extensive leaf necrosis and may be indicative of a lack of a mechanism to control $\mathrm{Na}^{+}$influx into blueberry leaves.
\end{abstract}

Rabbiteye and southern highbush blueberries require optimumquality water to thrive and produce. Water $\mathrm{pH}$ levels $>7.0$, total bicarbonates $\left(\mathrm{HCO}_{3}^{-}\right)>1.5 \mathrm{~mm}$, total $\mathrm{Na}^{+}>2.0 \mathrm{~mm}$, and total $\mathrm{Cl}^{-}$ $>4.0 \mathrm{~mm}$ indicate poor-quality water (Haby and Pennington, 1988). While the nutrient composition of rain and surface water seldom exceeds these thresholds, it is often inadequate during midsummer and early fall, when irrigation demands are high. Lower-quality groundwater, which sometimes exceeds the thresholds, must then be used. Groundwater in eastern Texas may contain $\mathrm{NaCl}$ or $\mathrm{NaHCO}_{3}{ }^{-}$salts or both, and often exceeds $15 \mathrm{mM} \mathrm{Na}^{+}, 6 \mathrm{mM} \mathrm{Cl}^{-}$, and $10 \mathrm{~mm} \mathrm{NaHCO}_{3}^{-}$(Texas Department of Health, 1990).

The most damaging effects of saline water on rabbiteye blueberry growth are reported to be due to high concentrations of $\mathrm{Na}^{+}$ rather than $\mathrm{HCO}_{3}^{-}$(Haby et al., 1986). Fresh weight gain of potted plants irrigated with well water containing $7.83 \mathrm{~mm} \mathrm{Na}^{+}$was only

Received for publication 27 Jan. 1992. Accepted for publication 7 June 1993. Contribution from the Texas Agricultural Experiment Station (paper no. TA 31180) and supported in part by the Expanded Research Area Fund of the experiment station. We thank Fincastle Nursery, La Rue, Texas, and Finch Nursery, Bailey, N.C., for generously donating the plants used in this study. The cost of publishing this paper was defrayed in part by the payment of page charges. Under postal regulations, this paper therefore must be hereby marked advertisement solely to indicate this fact.

${ }^{1}$ Assistant research scientist. Present address: Univ. of Arizona, Yuma Mesa Agricultural Center, Route 1, Box 40M, Somerton, AZ 85350.

${ }^{2}$ Associate horticulturist. Present address: Washington State Univ.-Long Beach Research and Extension Unit, Route 1, Box 570, Pioneer Rd., Long Beach, WA 98631.

${ }^{3}$ Professor of horticultural sciences.
$65 \%$ of the gain of plants irrigated with surface water (Haby et al., 1986). Similarly, Bush et al. (1990) compared field-grown plants treated with pond and saline well water. After 5 months, $39 \%$ of the plants irrigated with well water died, and, after 12 months, the mortality rate was $60 \%$. None of the plants irrigated with pond water died. Wright et al. (1992) found that $100 \mathrm{~mm} \mathrm{Na}{ }^{+}$reduced growth of 'Tifblue' rabbiteye shoots and roots by $62 \%$ and $57 \%$, respectively, compared to unsalinized controls. Growth of southern highbush blueberries was more severely affected by salinity. Additionally, saline water treatment reduced gas exchange of rabbiteye and southern highbush blueberries, and high concentrations of $\mathrm{Cl}^{-}$also seemed to damage the photosynthetic mechanism of blueberries (Wright et al., 1993).

Supplemental $\mathrm{Ca}^{2+}$ improves growth of many species exposed to salt stress. LaHaye and Epstein (1969) showed that adequate $\mathrm{Ca}^{2+}$ was a requirement for shoot and root growth in salt-stressed bean (Phaseolus vulgaris L.) plants. Similar results have been reported in shoots, roots, or both of maize (Zea mays) (Cramer et al., 1988; Maas and Grieve, 1987) and citrus (Ben-Hayyim et al. 1987; Bañuls et al., 1991). Additional $\mathrm{Ca}^{2+}$ seems to exclude $\mathrm{Na}^{+}$ from roots and leaves (Marschner, 1986). Although blueberries are calcifuges, plants that have low leaf $\mathrm{Ca}^{2+}$ concentration and thrive in soils low in $\mathrm{Ca}^{2+}$, we found that low concentrations of $\mathrm{Ca}^{2+}$ ameliorated the $\mathrm{Na}^{+}$effects on growth and gas exchange of blueberry plants when exposed to $\mathrm{Na}_{2} \mathrm{SO}_{4}$ and, to a lesser extent, $\mathrm{NaCl}$ (Wright et al., 1992, 1993).

The aim of this study was to determine the effect of a range of concentrations of $\mathrm{Na}_{2} \mathrm{SO}_{4}$ and $\mathrm{NaCl}$, with and without supplemen- 
tal $\mathrm{Ca}^{2+}$, on the ionic relations of salt-stressed rabbiteye and southern highbush blueberries. Sodium sulfate was applied to provide insight into the specific effect of $\mathrm{Na}^{+}$, since $\mathrm{SO}_{4}{ }^{2-}$ is absorbed slowly by plants (Marschner, 1986) and does not reduce blueberry growth (Spiers and Braswell, 1992). Salinization with $\mathrm{NaCl}$ was an alternative treatment to $\mathrm{Na}_{2} \mathrm{SO}_{4}$ and was designed to help understand the additional effect of $\mathrm{Cl}^{-}$on nutrient content of blueberry plants.

\section{Materials and Methods}

$\mathrm{Na}_{2} \mathrm{SO}_{4}$ experiment. Dormant 1-year-old 'Tifblue' and 'Brightwell' rabbiteye blueberries were potted in sand in the greenhouse on 15 Mar. 1988. Watering was by drip irrigation. Details of potting method and pretreatment irrigation were reported by Wright et al. (1992).

Treatments on 144 plants began on 15 May 1988 and consisted of 0,25 , and $100 \mathrm{mM} \mathrm{Na}^{+}\left(0,12.5\right.$, and $\left.50 \mathrm{~mm} \mathrm{Na}_{2} \mathrm{SO}_{4}\right)$ and $0,1,3$, and $10 \mathrm{mM} \mathrm{Ca}^{2+}$ applied with the remaining essential elements in the nutrient solution. Calcium and $\mathrm{Na}^{+}$levels were crossed, forming 12 total treatments. Because of only moderate solubility of $\mathrm{CaSO}_{4}$, only $70 \%$ of each $\mathrm{Ca}^{2+}$ treatment was $\mathrm{CaSO}_{4}$; the reminder was made up of $20 \% \mathrm{Ca}\left(\mathrm{NO}_{3}\right)_{2}$ and $10 \% \mathrm{CaCl}_{2}$. All treatments contained equimolar amounts of $\mathrm{NO}_{3}^{-}, \mathrm{NH}_{4}^{+}$, and $\mathrm{K}^{+}$. Plants received $\approx 400$ or $500 \mathrm{ml}$ solution daily, and sufficient nutrient solution was applied so that some solution leached from the containers. Solution $\mathrm{pH}$ and electrical conductivity (EC) (corrected to 25C) were recorded when solutions were prepared and each time they were replenished. These values, along with solution composition and sodium adsorption ratio (SAR), are reported in Table 1.

Plants were destructively sampled on 30 July 1988 after 76 days of treatment. Leaves and stems were separated from the roots, and roots were washed with distilled water to remove sand particles, then were blotted dry. Leaves, stems, and roots were dried at 60C for $48 \mathrm{~h}$ and ground to pass through a 1-mm sieve. Samples were digested using a procedure developed by Parkinson and Allen (1975). Nitrogen was analyzed colorimetrically using an autoanalyzer (Technicon Instruments Corp., Tarrytown, N.Y.). Sodium, $\mathrm{Ca}^{2+}$, and $\mathrm{K}^{+}$were analyzed using an inductively coupled plasma spectrophotometer (Allied Research Laboratories, Sunland, Calif.).
NaCl experiment. Dormant, 1-year-old, bare-root 'Tifblue' and 'Brightwell' rabbiteye blueberries and 'Sharpblue' southern highbush blueberries were planted on 15 Mar. 1989. The rabbiteye blueberries were handled in the same manner as in 1988, while the 'Sharpblue' plants were transplanted into sterilized 2750-ml pots containing sand and lined with fiberglass insulation (to prevent loss of media). 'Sharpblue' plants were pruned to a height of $20 \mathrm{~cm}$. The irrigation regime was the same as that for 1988 .

Plants were maintained with the complete nutrient solution until 15 May 1989, when treatments commenced. All plants except controls received $\mathrm{NaCl}$, but otherwise the compositions of the 12 nutrient solutions were the same as those of 1988 (Table 1). Solution $\mathrm{pH}$ and $\mathrm{EC}$ were again measured when the solutions were made and replenished. 'Sharpblue' plants were only treated with those solutions containing 0 and $10 \mathrm{mM} \mathrm{Ca}^{2+}$ because sufficient plants were not available to test all $\mathrm{Ca}^{2+}$ levels. Plants were destructively sampled on 17 July 1989 after 63 days of treatment. Sampling and analysis protocols were the same as those of the $\mathrm{Na}_{2} \mathrm{SO}_{4}$ experiment. Chloride was measured in addition to the other nutrients mentioned above and was extracted from ground tissue using a hot water extraction method (Ghosh and Drew, 1991), then analyzed coulombimetrically with a chloridometer (Haake Buchler Instruments, Saddle Brook, N.J.).

The experimental design for both sand culture experiments was a randomized complete block. Experiments involving 'Tifblue' and 'Brightwell' were $4\left(\mathrm{Ca}^{2+}\right.$ levels $) \times 3\left(\mathrm{Na}^{+}\right.$levels $) \times 2$ (cultivars) factorials with 6 replications, for a total of 144 plants. The experiment involving 'Sharpblue' was a $2 \times 3$ factorial with 4 replications, for a total of 24 plants. Data were analyzed using SAS' General Linear Model procedure (PROC GLM; SAS Institute, Cary, N.C.).

\section{Results}

Each cultivar responded differently to salinization with $\mathrm{Na}_{2} \mathrm{SO}_{4}$ and $\mathrm{NaCl}$, so data could not be averaged. The main effects of salinity and $\mathrm{Ca}^{2+}$ supplementation on nutrient concentration and distribution (as a percentage of total plant nutrient content) are described below and some interactions between salt concentration and $\mathrm{Ca}^{2+}$ are given graphically. Leaf $\mathrm{N}$ averaged $1.5 \%$ and was not influenced by $\mathrm{Ca}^{2+}$ or $\mathrm{Na}^{+}$treatments (data not shown).

$\mathrm{Na}_{2} \mathrm{SO}_{4}$ experiment: nutrient concentration of leaves. In gen-

Table 1. Mineral composition, sodium adsorption ratio (SAR), $\mathrm{pH}$, and electrical conductivity (EC) of nutrient solutions. ${ }^{\mathrm{z}}$

\begin{tabular}{|c|c|c|c|c|c|c|c|c|c|c|c|c|}
\hline \multicolumn{8}{|c|}{ Mineral composition (mM) } & \multirow[b]{2}{*}{ SAR } & \multicolumn{2}{|c|}{$\mathrm{pH}^{\mathrm{y}}$} & \multicolumn{2}{|c|}{$\mathrm{EC}\left(\mathrm{dS} \cdot \mathrm{m}^{-1}\right)$} \\
\hline Total $\mathrm{Na}^{\mathrm{x}+}$ & Total $\mathrm{Ca}^{2+}$ & $\mathrm{CaSO}_{4}$ & $\mathrm{Ca}\left(\mathrm{NO}_{3}\right)_{2}$ & $\mathrm{CaCl}_{2}$ & $\mathrm{KNO}_{3}$ & $\left(\mathrm{NH}_{4}\right)_{2} \mathrm{SO}_{4}$ & $\mathrm{~K}_{2} \mathrm{SO}_{4}$ & & $\mathrm{Na}_{2} \mathrm{SO}_{4}$ & $\mathrm{NaCl}$ & $\mathrm{Na}_{2} \mathrm{SO}_{4}$ & $\mathrm{NaCl}$ \\
\hline$\overline{0}$ & 0 & 0.0 & 0.0 & 0.0 & 4.0 & 4.0 & 0.0 & 0.0 & 6.1 & 5.4 & 1.22 & 1.18 \\
\hline 0 & 1 & 0.7 & 0.2 & 0.1 & 3.6 & 4.0 & 0.4 & 0.0 & 5.4 & 5.3 & 1.30 & 1.38 \\
\hline 0 & 3 & 2.1 & 0.6 & 0.3 & 2.8 & 4.0 & 1.2 & 0.0 & 5.2 & 5.0 & 1.62 & 1.81 \\
\hline 0 & 10 & 7.0 & 2.0 & 1.0 & 0.0 & 4.0 & 4.0 & 0.0 & 5.1 & 5.1 & 2.37 & 2.49 \\
\hline 25 & 0 & 0.0 & 0.0 & 0.0 & 4.0 & 4.0 & 0.0 & 31.0 & 5.5 & 6.4 & 3.23 & 3.80 \\
\hline 25 & 1 & 0.7 & 0.2 & 0.1 & 3.6 & 4.0 & 0.4 & 19.4 & 5.6 & 5.0 & 3.34 & 3.75 \\
\hline 25 & 3 & 2.1 & 0.6 & 0.3 & 2.8 & 4.0 & 1.2 & 13.0 & 6.1 & 5.1 & 3.72 & 3.80 \\
\hline 25 & 10 & 7.0 & 2.0 & 1.0 & 0.0 & 4.0 & 4.0 & 7.6 & 6.0 & 4.9 & 4.00 & 4.53 \\
\hline 100 & 0 & 0.0 & 0.0 & 0.0 & 4.0 & 4.0 & 0.0 & 124.0 & 6.7 & 5.3 & 8.87 & 8.80 \\
\hline 100 & 1 & 0.7 & 0.2 & 0.1 & 3.6 & 4.0 & 0.4 & 77.8 & 6.0 & 5.4 & 8.08 & 9.35 \\
\hline 100 & 3 & 2.1 & 0.6 & 0.3 & 2.8 & 4.0 & 1.2 & 52.3 & 6.2 & 5.0 & 8.92 & 9.55 \\
\hline 100 & 10 & 7.0 & 2.0 & 1.0 & 0.0 & 4.0 & 4.0 & 30.6 & 5.9 & 5.1 & 8.72 & 8.48 \\
\hline
\end{tabular}

${ }^{\mathrm{z} A d d i t i o n a l l y, ~ s o l u t i o n s ~ c o n t a i n e d ~} 0.1 \mathrm{mM} \mathrm{KH}_{2} \mathrm{PO}_{4}, 0.65 \mathrm{mM} \mathrm{MgSO}_{4}, 0.125 \mathrm{~mm} \mathrm{FeNa}\left(\mathrm{O}_{2} \mathrm{CCH}_{2}\right)_{2} \mathrm{NCH}_{2} \mathrm{CH}_{2} \mathrm{~N}_{\left(\mathrm{CH}_{2} \mathrm{CO}_{2}\right)_{2}, 10.9 \mu \mathrm{M} \mathrm{MnSO}}, 1.2 \mu \mathrm{M}$ $\mathrm{H}_{3} \mathrm{BO}_{3}, 0.2 \mu \mathrm{MuSO}_{4}, 0.076 \mu \mathrm{M} \mathrm{ZnSO}_{4}$, and $15 \mu \mathrm{M}\left(\mathrm{NH}_{4}\right)_{6} \mathrm{Mo}_{7} \mathrm{O}_{24}$.

${ }_{\mathrm{pH}}$ and $\mathrm{EC}$ values are means of at least three replications.

${ }^{x}$ Total $\mathrm{Na}^{+}$as $\mathrm{Na}_{2} \mathrm{SO}_{4}$ or $\mathrm{NaCl}$. 
eral, there was a significant influence of $\mathrm{Na}^{+}, \mathrm{Ca}^{2+}$, and the $\mathrm{Na}^{+} \times$ $\mathrm{Ca}^{2+}$ interaction on 'Tifblue' leaf mineral concentration and nutrient ratios (Table 2). There was an 54-fold linear increase in leaf $\mathrm{Na}^{+}$ when $\mathrm{Na}^{+}$in the external solution increased from 0 to $100 \mathrm{~mm}$. These increases in leaf $\mathrm{Na}^{+}$were diminished when $\mathrm{Ca}^{2+}$ was applied (Fig. 1). At $25 \mathrm{~mm} \mathrm{Na}^{+}$, plants receiving supplemental $\mathrm{Ca}^{2+}$ had lower leaf $\mathrm{Na}^{+}$concentrations. At $100 \mathrm{mM} \mathrm{Na}^{+}$, plants that received $1 \mathrm{mM} \mathrm{Ca}^{2+}$ had $\approx 20 \%$ lower $\mathrm{Na}^{+}$concentration.

The percentage of total plant $\mathrm{Na}^{+}$found in the leaves increased as $\mathrm{Na}^{+}$concentration in the external solution increased [Fig. 1 (inset), Table 3]. For those plants subjected to $100 \mathrm{~mm} \mathrm{Na}{ }^{+}$, the percentage of $\mathrm{Na}^{+}$found in leaves also increased with increasing $\mathrm{Ca}^{2+}$ concentration in the external solution. The percentage of total plant $\mathrm{Na}^{+}$found in the leaves of plants salinized with $100 \mathrm{~mm} \mathrm{Na} \mathrm{Na}^{+}$ but no additional $\mathrm{Ca}^{2+}$ was $\approx 50 \%$, while $70 \%$ of the $\mathrm{Na}^{+}$was found in leaves of plants given 3 or $10 \mathrm{~mm} \mathrm{Ca}^{2+}$.

'Tifblue' leaf $\mathrm{Ca}^{2+}$ concentrations decreased slightly as $\mathrm{Na}^{+}$ levels in the nutrient solution increased (Fig. 2). For unsalinized plants or for those given $25 \mathrm{mM} \mathrm{Na}^{+}$, any level of $\mathrm{Ca}^{2+}$ supplementation led to higher leaf $\mathrm{Ca}^{2+}$ levels, but for plants given $100 \mathrm{~mm}$ $\mathrm{Na}^{+}$, only $10 \mathrm{mM} \mathrm{Ca}^{2+}$ led to the greatest leaf $\mathrm{Ca}^{2+}$ concentrations.

The percentage of total plant $\mathrm{Ca}^{2+}$ found in the leaves did not vary with $\mathrm{Na}_{2} \mathrm{SO}_{4}(36 \%$ to $39 \%)$, but it decreased as $\mathrm{Ca}^{2+}$ concentration in the external solution increased (Table 3). For plants supplied with $10 \mathrm{~mm} \mathrm{Ca}{ }^{2+}$, the percentage of total plant $\mathrm{Ca}^{2+}$ found in the leaves was less than half that of plants supplied with lesser amounts of $\mathrm{Ca}^{2+}$. Thus, while leaf $\mathrm{Ca}^{2+}$ concentrations increased with increasing $\mathrm{Ca}^{2+}$ treatment levels (Table 2), these levels accounted for a decreasing percentage of the total $\mathrm{Ca}^{2+}$ in the plant, a result indicating that a greater percentage of the $\mathrm{Ca}^{2+}$ remained in the root.

Leaf $\mathrm{K}^{+}$concentrations generally decreased with increasing $\mathrm{Na}^{+}$. No clear effects of $\mathrm{Ca}^{2+}$ addition on leaf $\mathrm{K}^{+}$concentration were apparent with unsalinized plants (Fig. 3). Leaf $\mathrm{K}^{+}$concentrations decreased in salinized plants supplied with $\mathrm{Ca}^{2+}$. The percentage of total plant $\mathrm{K}^{+}$found in the leaf was $\approx 50 \%$ and did not vary significantly with $\mathrm{Na}^{+}$or $\mathrm{Ca}^{2+}$ treatment (Table 3 ).

Nutrient concentration of stems. The concentrations of $\mathrm{Na}^{+}$and $\mathrm{Ca}^{2+}$ in 'Tifblue' stems were less than in leaves, but, as with leaves, stem $\mathrm{Na}^{+}$concentrations increased with increasing $\mathrm{Na}^{+}$concentrations (Table 2), and showed small reductions (up to 23\%) after $\mathrm{Ca}^{2+}$ addition (data not shown). The percentage $\mathrm{Na}^{+}$found in stems was less than in the corresponding leaves (Table 3 ) and ranged from $6 \%$ to $12 \%$ of the total.

Stem $\mathrm{Ca}^{2+}$ increased as $\mathrm{Ca}^{2+}$ concentration in the external solutions increased and declined as salinization increased. Because the dry weight of stems was less than the weight of leaves (Wright et al., 1992), the stem $\mathrm{Ca}^{2+}$ represented a lesser percentage of total $\mathrm{Ca}^{2+}$ found in the plant. Stem $\mathrm{K}^{+}$concentrations declined with increasing $\mathrm{Na}^{+}$(Table 4) and were not affected by $\mathrm{Ca}^{2+}$ treatments.

Nutrient concentration of roots. Root $\mathrm{Na}^{+}$concentrations increased only 2-fold with increasing $\mathrm{Na}_{2} \mathrm{SO}_{4}$ treatments (Table 2), relative to the 50-fold increase in leaf $\mathrm{Na}^{+}$over the same treatment range (Table 2). Root $\mathrm{Na}^{+}$concentrations of plants receiving 100 mM Na${ }^{+}$were about one-third less than $\mathrm{Na}^{+}$concentrations in leaves of the same plants. Additionally, a smaller percentage of total plant $\mathrm{Na}^{+}$was found in the roots of these plants (Table 3) compared to the leaves, despite the greater dry mass of the roots (Wright et al.,

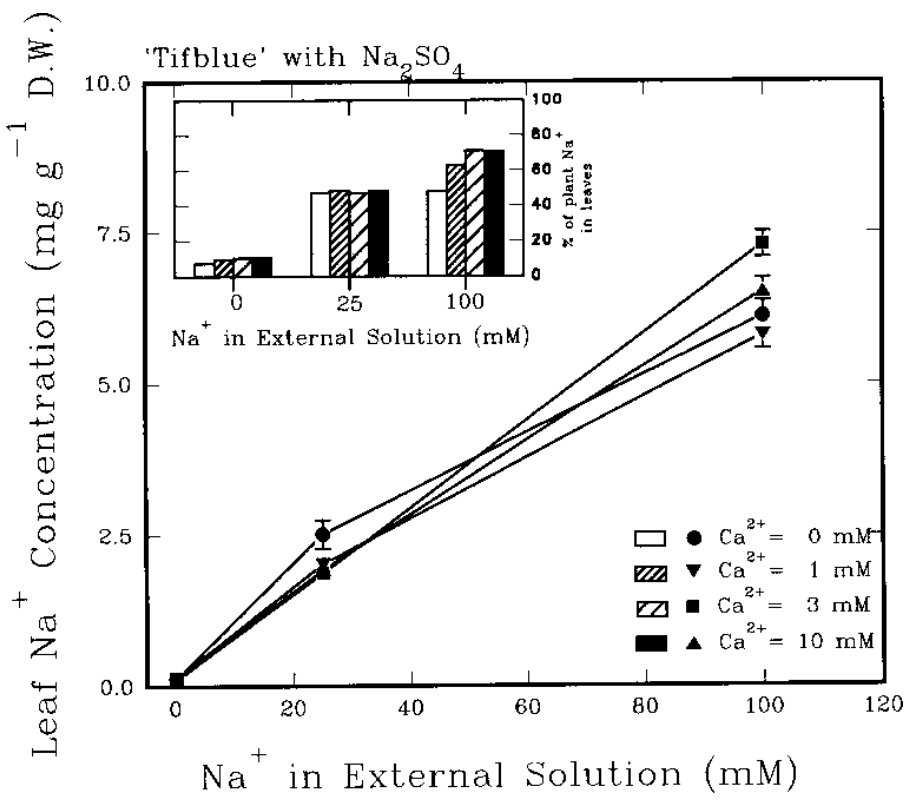

Fig. 1 Leaf $\mathrm{Na}^{+}$concentration and percentage of $\mathrm{Na}^{+}$found in the leaves (insert) of 'Tifblue' rabbiteye blueberry exposed to $\mathrm{NaSO}_{4}$ and supplemental $\mathrm{Ca}^{2+}$. Vertical bars indicate SE.

Table 2. Influence of $\mathrm{Na}_{2} \mathrm{SO}_{4}$ and $\mathrm{Ca}^{2+}$ treatments on leaf, stem, and root mineral nutrient concentration ( $\mu \mathrm{g} \cdot \mathrm{g}^{-1}$ dry weight) of 'Tifblue' rabbiteye blueberry plants.

\begin{tabular}{|c|c|c|c|c|c|c|c|c|c|}
\hline \multirow{2}{*}{$\begin{array}{l}\text { Treatment } \\
(\mathrm{mM})\end{array}$} & \multicolumn{3}{|c|}{$\mathrm{Na}^{+}$} & \multicolumn{3}{|c|}{$\mathrm{Ca}^{2+}$} & \multicolumn{3}{|c|}{$\mathrm{K}^{+}$} \\
\hline & Leaf & Stem & $\overline{\text { Root }}$ & Leaf & Stem & $\overline{\text { Root }}$ & Leaf & Stem & Root \\
\hline \multicolumn{10}{|l|}{$\mathrm{Ca}^{2+}$} \\
\hline 0 & 3122 & 948 & 4218 & 940 & 795 & 957 & 7066 & 5260 & 4430 \\
\hline 1 & 2621 & 800 & 3410 & 1356 & 1307 & 1645 & 5682 & 5607 & 5108 \\
\hline 3 & 3355 & 846 & 3137 & 1408 & 1388 & 2273 & 5583 & 5667 & 5346 \\
\hline \multirow[t]{2}{*}{10} & 2849 & 735 & 2359 & 1575 & 1543 & 15694 & 6261 & 5787 & 4448 \\
\hline & $* *$ & $\mathrm{~L}^{* *}$ & $\mathrm{~L}^{* *}$ & $\mathrm{~L}^{* *}$ & $\mathrm{~L}^{* *}$ & $\mathrm{~L}^{* *}$ & $Q^{* * *}$ & NS & $\mathrm{Q}^{* *}$ \\
\hline \multicolumn{10}{|l|}{$\mathrm{Na}^{+}\left(\mathrm{Na}_{2} \mathrm{SO}_{4}\right)$} \\
\hline 0 & 119 & 144 & 2144 & 1502 & 1377 & 7622 & 7158 & 6573 & 6099 \\
\hline 25 & 2072 & 885 & 3027 & 1353 & 1282 & 6106 & 5838 & 5611 & 4902 \\
\hline \multirow[t]{2}{*}{100} & 6467 & 1042 & 4482 & 1143 & 1151 & 2874 & 5532 & 4662 & 3578 \\
\hline & $\mathrm{L}^{* *}$ & $\mathrm{~L}^{* *}$ & $\mathrm{~L}^{* *}$ & $\mathrm{~L}^{* *}$ & $\mathrm{~L}^{* *}$ & $\mathrm{~L}^{* *}$ & $\mathrm{~L}^{* * *}$ & $\mathrm{~L}^{* *}$ & $\mathrm{~L}^{* *}$ \\
\hline \multicolumn{10}{|l|}{ Interaction } \\
\hline $\mathrm{Ca}^{2+} \times \mathrm{Na}_{2} \mathrm{SO}_{4}$ & $* *$ & $* *$ & NS & $* *$ & $* *$ & NS & $* *$ & NS & $* *$ \\
\hline
\end{tabular}

\footnotetext{
$\mathrm{Ns}^{* *}$ Nonsignificant or significant at $P \leq 0.01$, respectively; $\mathrm{L}=$ linear, $\mathrm{Q}=$ quadratic.
} 
Table 3. Influence of $\mathrm{Na}_{2} \mathrm{SO}_{4}$ and $\mathrm{Ca}^{2+}$ treatments on $\mathrm{Na}^{+}, \mathrm{Ca}^{2+}$, and $\mathrm{K}^{+}$distribution (percentage of total) to leaves, stems, and roots of 'Tifblue' rabbiteye blueberry plants.

\begin{tabular}{|c|c|c|c|c|c|c|c|c|c|}
\hline \multirow{2}{*}{$\begin{array}{l}\text { Treatment } \\
(\mathrm{mM})\end{array}$} & \multicolumn{3}{|c|}{$\mathrm{Na}^{+}$} & \multicolumn{3}{|c|}{$\mathrm{Ca}^{2+}$} & \multicolumn{3}{|c|}{$\mathrm{K}^{+}$} \\
\hline & Leaf & Stem & Root & Leaf & Stem & Root & Leaf & Stem & Root \\
\hline \multicolumn{10}{|l|}{$\mathrm{Ca}^{2+}$} \\
\hline 0 & 35 & 9 & 56 & 44 & 26 & 30 & 53 & 26 & 21 \\
\hline 1 & 41 & 9 & 50 & 46 & 25 & 29 & 49 & 28 & 23 \\
\hline 3 & 45 & 9 & 47 & 43 & 25 & 32 & 49 & 28 & 23 \\
\hline \multirow[t]{2}{*}{10} & 43 & 10 & 47 & 19 & 11 & 70 & 50 & 29 & 21 \\
\hline & $* *$ & NS & $* *$ & $* *$ & $* *$ & $* *$ & NS & NS & NS \\
\hline \multicolumn{10}{|l|}{$\mathrm{Na}^{+}\left(\mathrm{Na}_{2} \mathrm{SO}_{4}\right)$} \\
\hline 0 & 9 & 6 & 84 & 36 & 18 & 47 & 50 & 26 & 24 \\
\hline 25 & 48 & 12 & 40 & 39 & 22 & 39 & 49 & 28 & 23 \\
\hline \multirow[t]{2}{*}{100} & 63 & 9 & 27 & 39 & 26 & 36 & 50 & 28 & 19 \\
\hline & $* *$ & $* *$ & $* *$ & NS & $* *$ & $* *$ & NS & $*$ & $* *$ \\
\hline \multicolumn{10}{|l|}{ Interaction } \\
\hline $\mathrm{Ca}^{2+} \times \mathrm{Na}_{7} \mathrm{SO}_{4}$ & $* *$ & $* *$ & NS & NS & NS & NS & NS & NS & NS \\
\hline
\end{tabular}

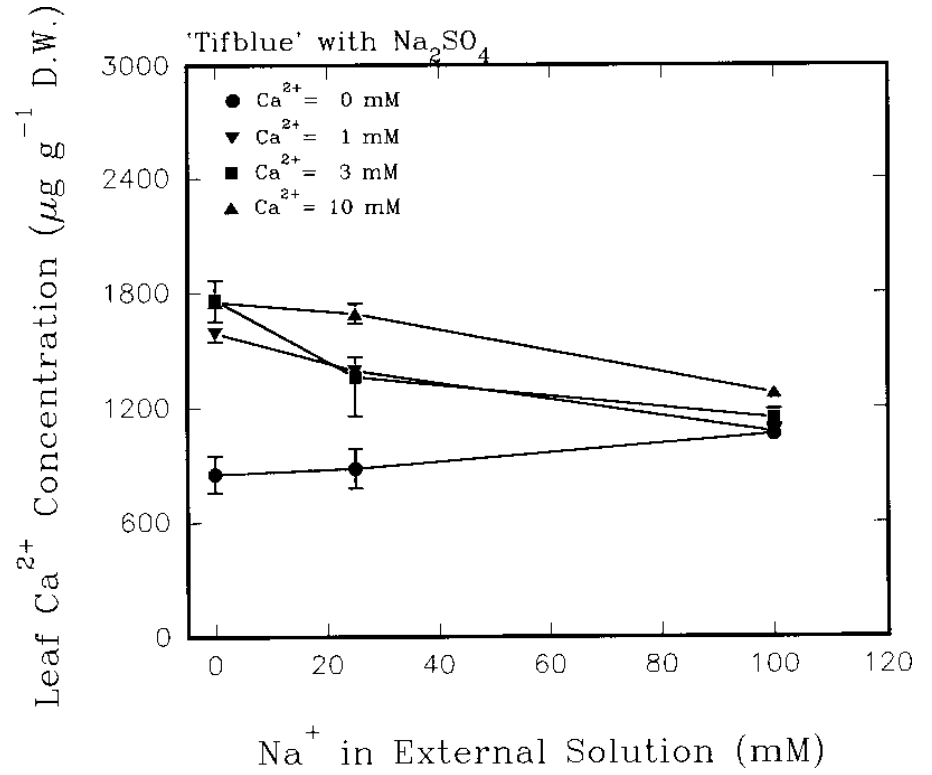

Fig. 2. Leaf $\mathrm{Ca}^{2+}$ concentration of 'Tifblue' rabbiteye blueberry exposed to $\mathrm{Na}_{2} \mathrm{SO}_{4}$ and supplemental $\mathrm{Ca}^{2+}$. Vertical bars indicate SE.

1992). Sodium concentrations and the percentage of total plant $\mathrm{Na}^{+}$ found in the roots decreased with increasing $\mathrm{Ca}^{2+}$ treatment levels. This contrasts with the increased percentage of $\mathrm{Na}^{+}$found in leaves of plants treated with $\mathrm{Ca}^{2+}$.

Calcium concentration and percentage of total plant $\mathrm{Ca}^{2+}$ in the roots of salinized plants decreased with increasing $\mathrm{Na}^{+}$treatment. Root $\mathrm{Ca}^{2+}$ concentration and percentage of total plant $\mathrm{Ca}^{2+}$ found in roots increased with added $\mathrm{Ca}^{2+}$ (Tables 2 and 3). For plants subjected to 3 and $10 \mathrm{~mm} \mathrm{Ca}^{2+}$, root $\mathrm{Ca}^{2+}$ concentration was up to 10 times greater than in the leaves (Table 2). This increase coincided with the decreased $\mathrm{Ca}^{2+}$ found in the leaves.

Potassium concentrations and percentage of total plant $\mathrm{K}^{+}$in roots were less than $\mathrm{K}^{+}$concentrations in 'Tifblue' leaves and stems, and both declined with increasing external $\mathrm{Na}_{2} \mathrm{SO}_{4}$ (Fig. 3, Table 3). Three $\mathrm{mm} \mathrm{Ca}^{2+}$ treatments led to the greatest root $\mathrm{K}^{+}$ concentrations, but $\mathrm{Ca}^{2+}$ treatments had no effect on the percentage of total plant $\mathrm{K}^{+}$found in the roots (Table 3).

Varietal differences in mineral nutrient concentration. Effects of $\mathrm{Na}_{2} \mathrm{SO}_{4}$ and $\mathrm{Ca}^{2+}$ on leaf and stem mineral nutrient concentra-

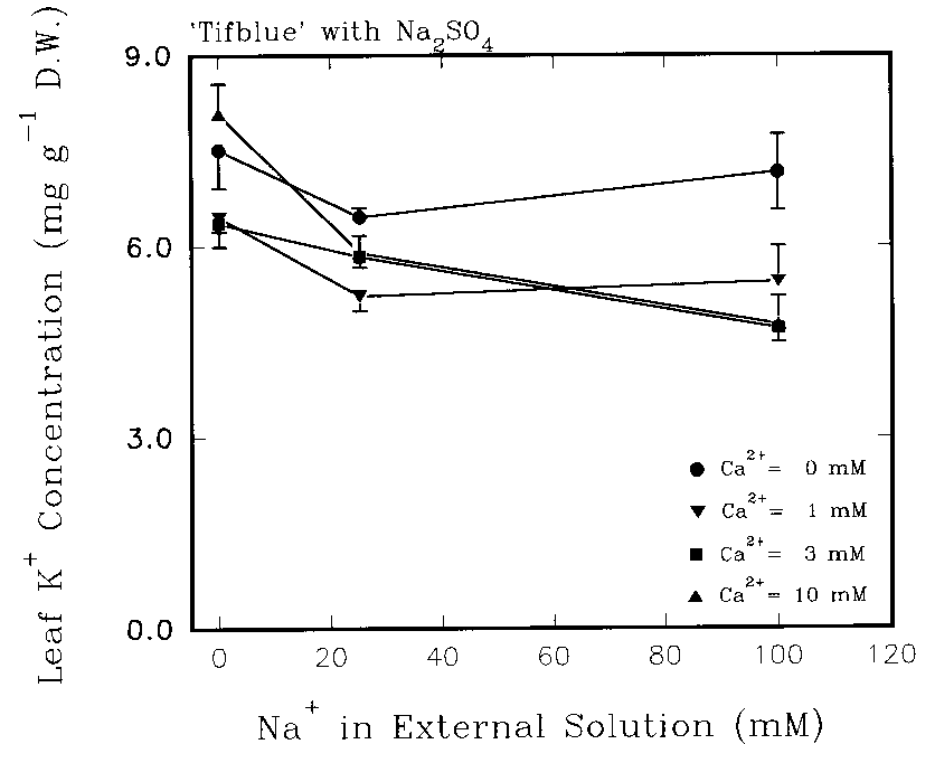

Fig. 3. Leaf $\mathrm{K}^{+}$concentration of 'Tifblue' rabbiteye blueberry exposed to $\mathrm{Na}_{2} \mathrm{SO}_{4}$ and supplemental $\mathrm{Ca}^{2+}$. Vertical bars indicate SE.

tions of 'Brightwell' plants were usually similar to the effects on 'Tifblue' leaves and stems (data not presented). However, leaf $\mathrm{Na}^{+}$ of 'Brightwell' supplied with $100 \mathrm{~mm} \mathrm{Na}^{+}$was $\approx 30 \%$ higher than in 'Tifblue'. Similarly, the leaf $\mathrm{Ca}^{2+}$ concentration of 'Brightwell' was usually greater than that of 'Tifblue', but the interaction effect was similar.

The effects of $\mathrm{Na}_{2} \mathrm{SO}_{4}$ and $\mathrm{Ca}^{2+}$ treatments on 'Brightwell' root element concentrations were also comparable to the effects on 'Tifblue' (data not presented), but root $\mathrm{Ca}^{2+}$ concentrations in 'Brightwell' were less than in 'Tifblue', while root $\mathrm{Na}^{+}$was greater. Root $\mathrm{K}^{+}$concentrations in both cultivars were similar. Distribution of $\mathrm{Na}^{+}, \mathrm{Ca}^{2+}$, and $\mathrm{K}^{+}$to leaves, shoots, and roots (\%) of 'Brightwell' plants was similar to their distribution in 'Tifblue'.

$\mathrm{NaCl}$ experiment: nutrient concentration of leaves. Increasing $\mathrm{NaCl}$ concentrations in the nutrient solution led to increases in 'Tifblue' leaf $\mathrm{Na}^{+}$and $\mathrm{Cl}^{-}$concentrations and decreases in leaf $\mathrm{Ca}^{2+}$ and $\mathrm{K}^{+}$(Table 4). These trends are comparable to the effects of $\mathrm{Na}_{2} \mathrm{SO}_{4}$ salinity on 'Tifblue'. However, leaf $\mathrm{Na}^{+}$concentrations of plants given 25 and $100 \mathrm{~mm}$ were nearly twice that of 'Tifblue' 
Table 4. Influence of $\mathrm{NaCl}$ and $\mathrm{Ca}^{2+}$ treatments on leaf, stem, and root mineral nutrient concentration ( $\mu \mathrm{g} \cdot \mathrm{g}^{-1}$ dry weight) of 'Tifblue' rabbiteye blueberry plants.

\begin{tabular}{|c|c|c|c|c|c|c|c|c|c|c|c|c|}
\hline \multirow{2}{*}{$\begin{array}{l}\text { Treatment } \\
(\mathrm{mM})\end{array}$} & \multicolumn{3}{|c|}{$\mathrm{Na}^{+}$} & \multicolumn{3}{|c|}{$\mathrm{Cl}^{-}$} & \multicolumn{3}{|c|}{$\mathrm{Ca}^{2+}$} & \multicolumn{3}{|c|}{$\mathrm{K}^{+}$} \\
\hline & Leaf & Stem & Root & Leaf & Stem & Root & Leaf & Stem & Root & Leaf & Stem & Root \\
\hline \multicolumn{13}{|l|}{$\mathrm{Ca}^{2+}$} \\
\hline 0 & 5307 & 1401 & 3940 & 5339 & 2546 & 2915 & 1519 & 1426 & 1449 & 7139 & 5538 & 5047 \\
\hline 1 & 4628 & 1283 & 3390 & 3771 & 1886 & 2936 & 1576 & 1395 & 1948 & 6595 & 5722 & 5457 \\
\hline 3 & 5457 & 1561 & 3486 & 6349 & 2234 & 3101 & 1705 & 1656 & 2976 & 6698 & 5949 & 5101 \\
\hline \multirow[t]{2}{*}{10} & 5844 & 1270 & 3145 & 6227 & 2217 & 3130 & 2001 & 1893 & 8791 & 6789 & 5437 & 5364 \\
\hline & NS & NS & NS & NS & NS & NS & $\mathrm{L}^{* *}$ & $\mathrm{~L}^{* *}$ & $\mathrm{~L}^{* *}$ & NS & NS & NS \\
\hline \multicolumn{13}{|l|}{$\mathrm{Na}^{+}(\mathrm{NaCl})$} \\
\hline 0 & 669 & 478 & 2015 & 917 & 928 & 1679 & 1864 & 1606 & 5541 & 7276 & 6395 & 6504 \\
\hline 25 & 4234 & 1497 & 3702 & 2990 & 2452 & 3607 & 1644 & 1574 & 3620 & 6251 & 5457 & 5039 \\
\hline \multirow[t]{2}{*}{100} & 10979 & 2166 & 5019 & 12252 & 3340 & 3799 & 1592 & 1595 & 1985 & 6865 & 5123 & 3950 \\
\hline & $\mathrm{L}^{* *}$ & $\mathrm{~L}^{* *}$ & $\mathrm{~L}^{* *}$ & $\mathrm{~L}^{* *}$ & $\mathrm{~L}^{* *}$ & $\mathrm{~L}^{* *}$ & $\mathrm{~L}^{* *}$ & NS & $\mathrm{L}^{*}$ & $\mathrm{Q}^{* *}$ & $\mathrm{~L}^{* *}$ & $\mathrm{~L}^{* *}$ \\
\hline \multicolumn{13}{|l|}{ Interaction } \\
\hline $\mathrm{Ca}^{2+} \times \mathrm{NaCl}$ & NS & NS & NS & NS & NS & NS & NS & NS & NS & NS & NS & NS \\
\hline
\end{tabular}

plants given equivalent levels of $\mathrm{Na}^{+}$as $\mathrm{Na}_{2} \mathrm{SO}_{4}$. Leaves of these plants contained $>50 \%$ of the total $\mathrm{Na}^{+}$(Table 5), which was more than twice the percentage of total plant $\mathrm{Na}^{+}$found in the leaves of unsalinized plants. Leaf $\mathrm{Cl}^{-}$concentrations of plants given $100 \mathrm{~mm}$ $\mathrm{NaCl}$ were $>1.2 \%$ (dry weight basis.). Leaf $\mathrm{Ca}^{2+}$ concentrations decreased linearly with increasing $\mathrm{Na}^{+}$. The percentage of total plant $\mathrm{Ca}^{2+}$ found in the leaves also declined in response to $\mathrm{Na}^{+}$ treatments as did the percentage of total plant $\mathrm{K}^{+}$. Supplemental $\mathrm{Ca}^{2+}$ treatments did not alter leaf nutrient $\mathrm{Na}^{+}$or $\mathrm{Cl}^{-}$concentrations, but led to increased leaf $\mathrm{Ca}^{2+}$ concentrations.

Nutrient concentration of stems. 'Tifblue' stem $\mathrm{Na}^{+}$and $\mathrm{Cl}^{-}$ concentrations also increased with increasing $\mathrm{Na}^{+}$in the external solution, but, in salinized plants, these concentrations were $60 \%$ to $70 \%$ less than in the leaves. Stem $\mathrm{Na}^{+}$concentrations were not influenced by $\mathrm{Ca}^{2+}$ treatments. The percentage of total plant $\mathrm{Na}^{+}$ found in the stems was not influenced by $\mathrm{Na}^{+}$or $\mathrm{Ca}^{2+}$ treatments (Table 5) and was $\approx 16 \%$. 'Tifblue' stem $\mathrm{Ca}^{2+}$ level increased linearly with increasing $\mathrm{Ca}^{2+}$ in the external solution, but $\mathrm{Ca}^{2+}$ addition had no other effect on any other nutrients. Stem $\mathrm{K}^{+}$ concentration decreased in response to increasing $\mathrm{NaCl}$ in the irrigation solution.

Nutrient concentration of roots. Root $\mathrm{Na}^{+}$and $\mathrm{Cl}^{-}$concentrations increased with increasing $\mathrm{Na}^{+}$treatments (Table 4) and were not affected by $\mathrm{Ca}^{2+}$ treatments. Root $\mathrm{Na}^{+}$and $\mathrm{Cl}^{-}$concentrations were less than one-half of the corresponding leaf $\mathrm{Na}^{+}$and $\mathrm{Cl}^{-}$ concentrations when $100 \mathrm{~mm} \mathrm{NaCl}$ was applied, a result suggesting that when salinity levels are high, both ions are preferentially transported to the leaves. Root $\mathrm{Ca}^{2+}$ concentration decreased with increasing $\mathrm{Na}^{+}$treatments, but increased with increasing $\mathrm{Ca}^{2+}$ treatments. In plants supplied with $10 \mathrm{~mm} \mathrm{Ca}^{2+}$, root $\mathrm{Ca}^{2+}$ concentration was more than four times the $\mathrm{Ca}^{2+}$ concentration of the leaves. This accumulation of $\mathrm{Ca}^{2+}$ in the roots is similar to the $\mathrm{Ca}^{2+}$ accumulation found in roots of plants treated with $\mathrm{Na}_{2} \mathrm{SO}_{4}$. Root $\mathrm{K}^{+}$ also decreased with increasing $\mathrm{Na}^{+}$in the irrigation solution. Total plant $\mathrm{Na}^{+}$in the roots decreased as $\mathrm{Na}^{+}$treatment concentrations increased (Table 5) and was not affected by $\mathrm{Ca}^{2+}$ treatments, but roots contained an increasing percentage of total plant $\mathrm{Ca}^{2+}$ with increasing $\mathrm{Ca}^{2+}$ treatments. Sodium and $\mathrm{Ca}^{2+}$ treatments did not affect the distribution of $\mathrm{K}^{+}$throughout the plants.

Varietal differences in mineral nutrient concentration. Effects of increasing $\mathrm{NaCl}$ salinity on leaf, stem, and root element concentrations were similar to that of 'Tifblue', except that $\mathrm{Na}^{+}$and $\mathrm{Cl}^{-}$ concentrations were less in 'Brightwell' than in 'Tifblue'. Chlo- ride concentrations of 'Brightwell' leaves and roots were only $55 \%$ and $32 \%$, respectively, of the concentrations found in 'Tifblue'. 'Brightwell' leaf and root $\mathrm{Ca}^{2+}$ increased with increasing $\mathrm{Ca}^{2+}$ in the solutions (data not presented). There were no other responses to $\mathrm{Ca}^{2+}$ addition. Percentage distribution of $\mathrm{Na}^{+}, \mathrm{Ca}^{2+}$, and $\mathrm{K}^{+}$in 'Brightwell' plants was similar to that of 'Tifblue', except that 'Brightwell' plants seemed to contain more $\mathrm{Na}^{+}$in the roots than in the leaves and stems.

'Sharpblue' leaf $\mathrm{Na}^{+}$concentrations increased as solution $\mathrm{Na}^{+}$ increased (Table 6). Medium (25 mm) and high (100 mm) $\mathrm{Na}^{+}$ treatment levels increased 'Sharpblue' leaf $\mathrm{Na}^{+}$to $0.8 \%$ and $2.3 \%$, respectively. Corresponding leaf $\mathrm{Cl}^{-}$concentrations were 0.2 and $1.5 \%$ (dry weight basis.) Extensive leaf necrosis was the result of these extremely high leaf $\mathrm{Na}^{+}$and $\mathrm{Cl}^{-}$concentrations. Percentage of total plant $\mathrm{Na}^{+}$found in the leaves increased from $37 \%$ to $57 \%$ as $\mathrm{Na}^{+}$concentrations in the irrigation solution increased from 0 to $100 \mathrm{~mm}$ (data not presented). Calcium treatments did not affect the percentage of $\mathrm{Na}^{+}$found in the leaves.

'Sharpblue' leaf $\mathrm{Ca}^{2+}$ concentrations were not affected by $\mathrm{Na}^{+}$ treatments, but were greater in plants treated with $10 \mathrm{mM} \mathrm{Ca}^{2+}$ than in plants not supplied with $\mathrm{Ca}^{2+}$. Nonetheless, the percentage of total plant $\mathrm{Ca}^{2+}$ found in the leaves declined with increasing $\mathrm{Ca}^{2+}$ treatments (data not presented), a result indicating a greater accumulation of $\mathrm{Ca}^{2+}$ in the stems and roots when $10 \mathrm{mM} \mathrm{Ca}^{2+}$ was applied. Percentage of total plant $\mathrm{Ca}^{2+}$ in the leaves was not affected by $\mathrm{Na}^{+}$treatments. Potassium concentrations in the leaf declined with increasing $\mathrm{Na}^{+}$and $\mathrm{Ca}^{2+}$ treatments (Table 6).

Stem and root nutrient concentrations of 'Sharpblue' were usually less than leaf nutrient concentrations. Stem $\mathrm{Na}^{+}$and $\mathrm{Cl}^{-}$ concentrations were greatest at $100 \mathrm{~mm} \mathrm{NaCl}$. Root $\mathrm{K}^{+}$and $\mathrm{Ca}^{2+}$ decreased with additional $\mathrm{NaCl}$, while root $\mathrm{Na}^{+}$and $\mathrm{Cl}^{-}$increased. However, the root $\mathrm{Na}^{+}$and $\mathrm{Cl}^{-}$concentrations were only $33 \%$ and $25 \%$, respectively, of the $\mathrm{Na}^{+}$and $\mathrm{Cl}^{-}$concentration in the leaves. High $(10 \mathrm{~mm}) \mathrm{Ca}^{2+}$ treatment led to increased $\mathrm{Ca}^{2+}$ in the stem, compared to controls.

\section{Discussion}

Most crop species that can be characterized as glycophytes avoid salinity damage by salt exclusion (Greenway and Munns, 1980). At low salt concentrations, $\mathrm{Na}^{+}$is excluded from the leaves by roots that actively pump $\mathrm{Na}^{+}$out of cells into the external medium. Xylem parenchyma cells in the basal (older) zones of the 
Table 5. Influence of $\mathrm{NaCl}$ and $\mathrm{Ca}^{2+}$ treatments on $\mathrm{Na}^{+}, \mathrm{Ca}^{2+}$, and $\mathrm{K}^{+}$distribution (percentage of total) to leaves, stems, and roots of 'Tifblue' rabbiteye blueberry plants.

\begin{tabular}{|c|c|c|c|c|c|c|c|c|c|}
\hline \multirow{2}{*}{$\begin{array}{l}\text { Treatment } \\
(\mathrm{mM})\end{array}$} & \multicolumn{3}{|c|}{$\mathrm{Na}^{+}$} & \multicolumn{3}{|c|}{$\mathrm{Ca}^{2+}$} & \multicolumn{3}{|c|}{$\mathrm{K}^{+}$} \\
\hline & Leaf & Stem & Root & Leaf & Stem & Root & Leaf & Stem & Root \\
\hline \multicolumn{10}{|l|}{$\overline{\mathrm{Ca}^{2+}}$} \\
\hline 0 & 42 & 16 & 42 & 39 & 36 & 26 & 44 & 34 & 22 \\
\hline 1 & 44 & 17 & 39 & 39 & 32 & 29 & 44 & 35 & 22 \\
\hline 3 & 43 & 17 & 40 & 34 & 29 & 37 & 43 & 34 & 23 \\
\hline \multirow{2}{*}{10} & 48 & 15 & 37 & 25 & 24 & 52 & 42 & 33 & 25 \\
\hline & NS & NS & NS & $* *$ & $* *$ & $* *$ & NS & NS & NS \\
\hline \multicolumn{10}{|l|}{$\mathrm{Na}^{+}(\mathrm{NaCl})$} \\
\hline 0 & 25 & 17 & 59 & 37 & 25 & 38 & 45 & 31 & 24 \\
\hline 25 & 53 & 16 & 31 & 35 & 28 & 37 & 45 & 32 & 23 \\
\hline \multirow[t]{2}{*}{100} & 55 & 16 & 28 & 30 & 38 & 33 & 40 & 39 & 21 \\
\hline & $* *$ & NS & $* *$ & $* *$ & $* *$ & NS & $* *$ & $* *$ & NS \\
\hline \multicolumn{10}{|l|}{ Interaction } \\
\hline $\mathrm{Ca}^{2+} \times \mathrm{NaCl}$ & NS & NS & NS & $* *$ & NS & $* *$ & NS & NS & NS \\
\hline
\end{tabular}

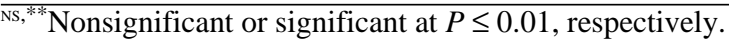

Table 6. Influence of $\mathrm{NaCl}$ and $\mathrm{Ca}^{2+}$ treatments on leaf mineral nutrient concentration ( $\mu \mathrm{g} \cdot \mathrm{g}^{-1}$ dry weight) of 'Sharpblue' southern highbush blueberry plants.

\begin{tabular}{|c|c|c|c|c|c|c|c|c|c|c|c|c|}
\hline \multirow{2}{*}{$\begin{array}{l}\text { Treatment } \\
(\mathrm{mM})\end{array}$} & \multicolumn{3}{|c|}{$\mathrm{Na}^{+}$} & \multicolumn{3}{|c|}{$\mathrm{Cl}^{-}$} & \multicolumn{3}{|c|}{$\mathrm{Ca}^{2+}$} & \multicolumn{3}{|c|}{$\mathrm{K}^{+}$} \\
\hline & Leaf & Stem & Root & Leaf & Stem & Root & Leaf & Stem & Root & Leaf & Stem & Root \\
\hline \multicolumn{13}{|l|}{$\mathrm{Ca}^{2+}$} \\
\hline 0 & 10966 & 4535 & 7214 & 5375 & 1572 & 3596 & 2739 & 2442 & 2645 & 10625 & 5229 & 7275 \\
\hline \multirow[t]{2}{*}{10} & 10848 & 6081 & 6509 & 7359 & 2229 & 4044 & 4025 & 3983 & 9548 & 9744 & 5079 & 7014 \\
\hline & NS & NS & NS & NS & NS & NS & $* *$ & $* *$ & $* *$ & $*$ & NS & NS \\
\hline \multicolumn{13}{|l|}{$\mathrm{Na}^{+}(\mathrm{NaCl})$} \\
\hline 0 & 1460 & 1088 & 2657 & 1282 & 609 & 2884 & 3721 & 3236 & 8117 & 13226 & 6811 & 9233 \\
\hline 25 & 8244 & 4990 & 9582 & 2173 & 1264 & 4228 & 2726 & 2220 & 5774 & 9186 & 4959 & 7893 \\
\hline \multirow[t]{2}{*}{100} & 23017 & 9847 & 8346 & 15646 & 3830 & 4349 & 3698 & 4151 & 4398 & 8143 & 3691 & 4308 \\
\hline & $\mathrm{L}^{* *}$ & $\mathrm{~L}^{* *}$ & $\mathrm{~L}^{* *}$ & $\mathrm{~L}^{* *}$ & $\mathrm{~L}^{* *}$ & $\mathrm{~L}^{* *}$ & NS & $\mathrm{Q}^{* *}$ & $\mathrm{~L}^{*}$ & $\mathrm{~L}^{* *}$ & $\mathrm{~L}^{* *}$ & $\mathrm{~L}^{* *}$ \\
\hline \multicolumn{13}{|l|}{ Interaction } \\
\hline $\mathrm{Ca}^{2+} \times \mathrm{NaCl}$ & NS & NS & NS & NS & NS & NS & NS & NS & NS & NS & NS & NS \\
\hline
\end{tabular}

$\overline{\mathrm{Ns}, *, * *}$ Nonsignificant or significant at $P \leq 0.05$ or 0.01 , respectively; $\mathrm{L}=$ linear, $\mathrm{Q}=$ quadratic.

roots also accumulate $\mathrm{Na}^{+}$in the vacuole, thereby removing $\mathrm{Na}^{+}$ from the xylem sap.

Sodium exclusion is an energy-dependent process, which, in some species, seems to be limited when external salt concentrations are high (Drew and Dikumwin, 1985). Ion transport processes at the plasmalemma can be inhibited in the presence of excess salt. Chung and Matsumoto (1989) found that $\mathrm{K}^{+}-\mathrm{Mg}^{2+}$ ATPase activity in the roots of cucumber exposed to $200 \mathrm{~mm} \mathrm{NaCl}$ were always less than activities of control plants. Additionally, Van Steveninck et al. (1982) proposed that the inability of Lupinus luteus to restrict $\mathrm{Na}^{+}$transport to leaves was because of an inability to sequester $\mathrm{Na}^{+}$in the vacuoles of root cortical cells. Their research was supported by more recent work of Maathius and Prins (1990), who demonstrated that $\mathrm{NaCl}$ decreased the open probability of voltage- and $\mathrm{Ca}^{2+}$-dependent tonoplast channels in saltsensitive plantago species.

When these exclusion systems are ineffective or fail due to high salinity, $\mathrm{Na}^{+}$concentrations in the leaves can rise dramatically. Evidence of exclusion failure has been documented in pistachio (Pistacia vera), in which root $\mathrm{Na}^{+}$concentrations were five times greater than leaf concentrations until soil solution $\mathrm{Na}^{+}$surpassed $125 \mathrm{~mm}$ (Picchioni et al., 1990), and in bean (P. vulgaris), in which $\mathrm{Na}^{+}$concentration of leaves gradually increased as external $\mathrm{Na}^{+}$ increased (Jacoby, 1964). In highbush blueberry (Vaccinium corymbosum cv. Bluecrop) leaf $\mathrm{Na}^{+}$concentrations gradually increased to a maximum of $5.4 \mathrm{mg} \cdot \mathrm{g}^{-1}$ in plants grown in $50 \mathrm{~mm}$ $\mathrm{NaCl}$, a leaf concentration nearly twice that found in the roots (Muralitharan et al., 1992). In the present study with rabbiteye and southern highbush blueberries, leaf $\mathrm{Na}^{+}$concentrations of rabbiteye plants provided with $100 \mathrm{~mm} \mathrm{NaCl}$ increased to $\approx 10.9 \mathrm{mg} \cdot \mathrm{g}^{-1}$, and $\mathrm{Na}^{+}$seemed to be accumulated in the leaves, because leaf $\mathrm{Na}^{+}$ concentration was also twice that of the roots (Table 4). Since the percentage of total plant $\mathrm{Na}^{+}$found in the leaves also increased (to a maximum of $50 \%$ to $70 \%$ ) with increasing $\mathrm{Na}^{+}$treatment levels (Table 5), it can be concluded that $\mathrm{Na}^{+}$exclusion failed. The accumulation becomes inevitable when transpiration draws salts up the xylem into the leaves in the absence of salt glands.

Similar differences between leaf and root $\mathrm{Na}^{+}$concentrations occurred in rabbiteye plants provided $100 \mathrm{~mm} \mathrm{Na}{ }^{+}$as $\mathrm{Na}_{2} \mathrm{SO}_{4}$, but there was little difference between leaf and root $\mathrm{Na}^{+}$concentrations of rabbiteye plants given $25 \mathrm{~mm} \mathrm{Na}$. High salt treatments led to leaf and root necrosis and reduced shoot growth and caused stunting and abnormal branching of roots (Wright et al., 1992). Thus, while our data partially support the findings of Spiers (1983), who concluded that rabbiteye blueberries lack a mechanism to restrict $\mathrm{Na}^{+}$uptake to shoots, there is the possibility that such a mechanism exists, but is rendered ineffective at high external $\mathrm{Na}^{+}$ concentrations and may play a greater role at lower $\mathrm{Na}^{+}$concentra- 
tions such as the $25 \mathrm{~mm}$ concentration used in this study.

Our previous work suggests that salt damage to rabbiteye blueberries is more extensive with $\mathrm{NaCl}$ than with $\mathrm{Na}_{2} \mathrm{SO}_{4}$ (Wright et al., 1992, 1993). Data collected here showed that root and leaf $\mathrm{Na}^{+}$concentrations of plants subjected to $\mathrm{Na}_{2} \mathrm{SO}_{4}$ were often lower than $\mathrm{Na}^{+}$concentrations of plants subjected to $\mathrm{NaCl}$ salinity (Tables 2 and 4). These differences were not due to increased transpiration, because $\mathrm{Na}_{2} \mathrm{SO}_{4}$-salinized plants transpired more than NaCl-salinized plants (Wright et al., 1993). 'Bluecrop' highbush blueberry exposed to $\mathrm{Na}_{2} \mathrm{SO}_{4}$ and $\mathrm{NaCl}$ showed similar differences in transpiration (Muralitharan et al., 1992). Manchanda and Sharma (1989) also found that, at higher salinity, the $\mathrm{Na}^{+}$ concentration in chickpea shoots was greater in $\mathrm{Cl}^{-}$dominated than in $\mathrm{SO}_{4}^{-2}$ dominated salinity. In contrast, Boursier and Läuchli (1990) found that $\mathrm{Na}^{+}$concentrations in the leaf blade of sorghum was greater with $\mathrm{Na}_{2} \mathrm{SO}_{4}$ than with $\mathrm{NaCl}$-treated plants. They suggest that the difference is because the accumulation of $\mathrm{Na}^{+}$in the vacuoles of root cells is limited by the relatively slower uptake of $\mathrm{SO}_{4}^{-2}$ into those vacuoles compared to $\mathrm{Cl}^{-}$uptake. Differences in transport rate across the tonoplast and plasma membrane are likely to be determined in part by the presence of suitable co-ions (Marschner, 1986) and also by plant species.

Exclusion of $\mathrm{Cl}^{-}$from blueberry leaves was no more effective than for $\mathrm{Na}^{+}$at high external $\mathrm{NaCl}$. Leaf $\mathrm{Cl}^{-}$concentrations were at least three times greater than root $\mathrm{Cl}^{-}$concentrations after 63 days of treatment. Such high leaf $\mathrm{Cl}^{-}$concentrations emphasize the possibility that $\mathrm{Cl}^{-}$and $\mathrm{Na}^{+}$may both be damaging to growth and gas exchange of blueberries. Chloride is known to be damaging to bean (Lessani and Marschner, 1978) and a number of fruit species (Brown et al., 1958; Ehlig, 1965).

Accumulation of $\mathrm{Na}^{+}, \mathrm{Cl}^{-}$, or both depended on species and cultivar. With $\mathrm{Na}_{2} \mathrm{SO}_{4}$ as the salt source, $\mathrm{Na}^{+}$concentrations in 'Brightwell' were usually greater than those in 'Tifblue', but visual damage appeared equivalent. Calcium and $\mathrm{K}^{+}$concentrations were also greater in 'Brightwell' than in 'Tifblue'. When $\mathrm{NaCl}$ was the salt, 'Tifblue' plants had higher $\mathrm{Na}^{+}$and $\mathrm{Cl}^{-}$and lower $\mathrm{Ca}^{2+}$ than 'Brightwell'. There was little difference in salinity damage or in growth between the two rabbiteye cultivars (Wright et al., 1992). 'Sharpblue' southern highbush blueberries accumulated more $\mathrm{Na}^{+}$and $\mathrm{Cl}^{-}$than either rabbiteye cultivar; 'Sharpblue' leaf $\mathrm{Na}^{+}$and $\mathrm{Cl}^{-}$concentrations were 2.1 and 1.3 times greater than those of 'Tifblue'. These high concentrations of $\mathrm{Na}^{+}$and $\mathrm{Cl}^{-}$likely caused the extensive leaf necrosis and rapid decline of photosynthesis in 'Sharpblue' compared to the rabbiteye cultivars (Wright et al., 1992, 1993). These differences in nutrient uptake may be due to differing characteristics of the parent material and, in the case of 'Sharpblue', to differing sensitivities of $V$. corymbosum and $V$. darrowi.

High $\mathrm{Ca}^{2+}$ treatments reduced accumulation of $\mathrm{Na}^{+}$in stems and roots of 'Tifblue' and 'Brightwell' plants subjected to $100 \mathrm{~mm} \mathrm{Na}^{+}$ as $\mathrm{Na}_{2} \mathrm{SO}_{4}$ (Fig. 1). These treatments also led to the greatest accumulation of $\mathrm{Ca}^{2+}$ in the roots (Table 2), a result suggesting that sodium exclusion from the roots relies on high $\mathrm{Ca}^{2+}$ levels (Marschner, 1986). This result possibly supports research by Rains and Epstein (1967), Jacoby and Hanson (1985) and Cramer et al. (1987) indicating that, at high external $\mathrm{Na}^{+}$concentrations, $\mathrm{Na}^{+}$ influx into the roots was inhibited in the presence of adequate $\mathrm{Ca}^{2+}$. However, for leaves, these high $\mathrm{Ca}^{2+}$ levels led to the highest $\mathrm{Na}^{+}$ concentrations and the highest percentage of total plant $\mathrm{Na}^{+}$found in the leaves. For plants salinized with $100 \mathrm{~mm} \mathrm{Na}_{2} \mathrm{SO}_{4}$, growth and gas exchange was reduced in plants supplied with high levels of $\mathrm{Ca}^{2+}$ (Wright et al., 1992, 1993). This result indicates that $\mathrm{Na}^{+}$may simply pass through roots and stems and accumulate in leaves when $\mathrm{Ca}^{2+}$ is high, thus leading to salinity damage. Our results also suggest that high concentrations of supplemental $\mathrm{Ca}^{2+}$ may damage mechanisms that limit $\mathrm{Na}^{+}$influx into blueberry leaves. We are unaware of any reports of this phenomena occurring in any other species, but it should be borne in mind that blueberry is essentially a calcifuge in its nutrition.

Adding $\mathrm{NaCl}$ increased leaf $\mathrm{Na}^{+}$and $\mathrm{Cl}^{-}$, lowered leaf $\mathrm{Ca}^{2+}$, and decreased the total percentage $\mathrm{Ca}^{2+}$ found in the leaves. Neither $\mathrm{Na}^{+}$or $\mathrm{Cl}^{-}$concentrations of leaves, stems, or roots were altered by supplemental $\mathrm{Ca}^{2+}$. This suggests that the greater concentrations of $\mathrm{Na}^{+}$found in plants treated with $\mathrm{NaCl}$ or the $\mathrm{Cl}^{-}$anion may have masked the beneficial effects of $\mathrm{Ca}^{2+}$ or damaged mechanisms by which the plant might normally limit $\mathrm{Na}^{+}$uptake (Drew and Dikumwin, 1985). Possible sites of damage include the plasmalemma, in which high concentrations of $\mathrm{Na}^{+}$have been shown to displace $\mathrm{Ca}^{2+}$ (Cramer et al., 1985; Lynch et al., 1987, Suhayda et al., 1990), thus leading to decreased membrane resistance. High $\mathrm{Na}^{+}$concentrations also lower ATPase activity necessary for active efflux of $\mathrm{Na}^{+}$from the cytoplasm (Chung and Matsumoto, 1989).

The inability of $\mathrm{Ca}^{2+}$ to limit $\mathrm{Na}^{+}$uptake in plants treated with $\mathrm{NaCl}$ may involve metabolic damage due to $\mathrm{Cl}^{-}$. Excessive $\mathrm{Cl}^{-}$is known to inhibit growth (Ballinger, 1962; Manchanda and Sharma, 1989), and photosynthesis (Bongi and Loreto, 1989). However, the effects of high levels of $\mathrm{Cl}^{-}$on other facets of plant metabolism have received little attention.

Increasing $\mathrm{Na}^{+}$also decreased $\mathrm{K}^{+}$concentrations in leaves, stems, and roots. Adequate $\mathrm{Ca}^{2+}$ has been shown to increase root $\mathrm{K}^{+}$ levels in citrus (Bañuls et al., 1991) and maintain $\mathrm{K}^{+} / \mathrm{Na}^{+}$selectivity in cotton roots (Cramer et al., 1987). Potassium concentrations in leaves of highbush blueberries dropped as $\mathrm{NaCl}$ or $\mathrm{Na}_{2} \mathrm{SO}_{4}$ treatments increased (Muralitharan et al., 1992). But, in our study, leaf and root $\mathrm{Na}^{+}$increased and $\mathrm{K}^{+}$decreased with increasing $\mathrm{Ca}^{2+}$ in rabbiteye plants treated with $\mathrm{NaCl}$. This again suggests that $\mathrm{Ca}^{2+}$ was ineffective in limiting $\mathrm{Na}^{+}$uptake in blueberry plants treated with $\mathrm{NaCl}$.

In summary, these data suggest that a lack of $\mathrm{Na}^{+}$exclusion mechanism may be responsible for high leaf $\mathrm{Na}^{+}$concentrations in plants treated with $100 \mathrm{~mm} \mathrm{Na}_{2} \mathrm{SO}_{4}$ or $\mathrm{NaCl}$. Sodium chloride led to higher leaf $\mathrm{Na}^{+}$concentrations than $\mathrm{Na}_{2} \mathrm{SO}_{4}$, possibly because $\mathrm{Na}^{+}$and $\mathrm{Cl}^{-}$disrupt metabolism. Calcium effectively lowered leaf $\mathrm{Na}^{+}$concentration when $\mathrm{Na}_{2} \mathrm{SO}_{4}$ and not $\mathrm{NaCl}$ was the salt source. Sodium treatments also led to decreased $\mathrm{K}^{+}$and $\mathrm{Ca}^{2+}$ concentrations in the leaves. Excessive accumulation of $\mathrm{Na}^{+}$and $\mathrm{Cl}^{-}$in leaves parallels the onset of growth retardation, slower photosynthesis, and leaf necrosis recorded earlier for these experiments.

\section{Literature Cited}

Ballinger, W.E. 1962. Studies of sulfate and chloride ion effects upon 'Wolcott' blueberry growth and composition. Proc. Amer. Soc. Hort. Sci. 80:331-339.

Bañuls, J., F. Legaz, and E. Primo-Millo. 1991. Salinity-calcium interactions on growth and ionic concentrations of citrus plants. Plant \& Soil 133:39-46.

Ben-Hayyim, G., U. Kafkafi, and R. Ganmore-Neumann. 1987. Role of internal potassium in maintaining growth of cultured citrus cells on increasing $\mathrm{NaCl}$ and $\mathrm{CaCl}_{2}$ concentrations. Plant Physiol. 85:434-439.

Bongi, G. and F. Loreto. 1989. Gas-exchange properties of salt-stressed olive (Olea europea L.) leaves. Plant Physiol. 90:1408-1416.

Boursier, P. and A. Läuchli. 1990. Growth responses and mineral nutrient relations of salt-stressed sorghum. Crop Sci. 30:1226-1233.

Brown, J.W., C.H. Wadleigh, and H.E. Hayward. 1953. Foliar analysis of stone fruit and almond trees on saline substrates. Proc. Amer. Soc. Hort. Sci. 61:49-54. 
Bush, E.W., D.M. Lancaster, and C.E. Johnson. 1990. Effects of water quality on field-grown rabbiteye blueberries. Louisiana Agr. 32:14-15, 21.

Chung, G.C. and H. Matsumoto. 1989. Localization of the NaCl-sensitive membrane fraction in cucumber roots by centrifugation on a sucrose density gradient. Plant Cell Physiol. 30:1133-1138.

Cramer, G.R., E. Epstein, and A. Läuchli. 1988. Kinetics of root elongation of maize in response to short-term exposure to $\mathrm{NaCl}$ and elevated calcium concentration. J. Expt. Bot. 39:1513-1522.

Cramer, G.R., J. Lynch, A Läuchli, and E. Epstein, 1987. Influx of $\mathrm{Na}^{+}$, $\mathrm{K}^{+}$, and $\mathrm{Ca}^{2+}$ into roots of salt-stressed cotton seedlings. Plant Physiol. 79:207-211.

Cramer, G.R., A. Läuchli, and V.S. Polito. 1985. Displacement of $\mathrm{Ca}^{2+}$ by $\mathrm{Na}^{+}$from the plasmalemma of root cells. Plant Physiol. 79:207-211.

Drew, M.C and E. Dikumwin. 1985. Sodium exclusion from the shoots by roots of Zea mays (cv. LG 11) and its breakdown with oxygen deficiency. J. Expt. Bot. 36:55-62.

Ehlig, C.F. 1965. Salt tolerance of raspberry, boysenberry, and blackberry. Proc. Amer. Soc. Hort. Sci. 85:318-324.

Ghosh, G. and M.C. Drew. 1991. Comparison of analytical methods for extraction of chloride from plant tissue using ${ }^{36} \mathrm{Cl}^{-}$as a tracer. Plant \& Soil 136:265-268.

Greenway, H. and R. Munns. 1980. Mechanisms of salt-tolerance in non-halophytes. Annu. Rev. Plant Physiol. 31:149-190.

Haby, V.A. and H.D. Pennington. 1988. Irrigation water source and quality, p. 2-1-2-13. In: M.L. Baker, K.D. Patten, E.W. Neuendorff, and C. Lyons (eds.). Texas blueberry handbook - Production and marketing. Texas Agr. Ext. Serv., Texas Agr. Expt. Sta., Texas A \& M Univ. System, College Station.

Haby, V.A., K.D. Patten, D.L. Cawthon, B.B. Kresja, E.W. Neuendorff, J.V. Davis, and S.C. Peters. 1986. Response of container-grown rabbiteye blueberry plants to irrigation water quality and soil type. J. Amer. Soc. Hort. Sci. 111:332-337.

Jacoby, B. 1964. Function of bean roots and stems in sodium retention. Plant Physiol. 39:445-449.

Jacoby, B. and J.B. Hanson. 1985. Controls on ${ }^{22} \mathrm{Na}^{+}$influx in corn roots. Plant Physiol. 77:930-934.

LaHaye, P.A. and E. Epstein. 1969. Salt toleration by plants: Enhancement with calcium. Science 166:395-396.

Lessani, H. and H. Marschner. 1978. Relation between salt tolerance and long-distance transport of sodium and chloride in various crop species. Austral. J. Plant Physiol. 5:27-37.

Lynch, J., G.R. Cramer, and A. Läuchli. 1987. Salinity reduces membrane associated calcium in corn root protoplasts. Plant Physiol. 83:390-394.

Maas, E.V. and C.M. Grieve. 1987. Sodium-induced calcium deficiency in salt-stressed corn. Plant Cell Environ. 10:559-564.

Maathius, F.J.M. and H.B.A. Prins. 1990. Patch clamp studies on root cell vacuoles of a salt-stressed and salt-sensitive plantago species. Plant Physiol. 92:23-28.

Manchanda, H.R. and S.K. Sharma. 1989. Tolerance of chloride and sulphate salinity in chickpea (Cicer arietinum). J. Agr. Sci. Cambridge 113:407-410.

Marschner, H. 1986. Mineral nutrition in higher plants. Academic Press, London.

Muralitharan, M.S., R.F.M. Van Steveninck, and S.F. Chandler. 1990. Growth characteristics and ion contents on non-selected and salt-selected callus lines of highbush blueberry (Vaccinium corymbosum) cultivars Blue Crop and Denise Blue. Plant Cell Rpt. 9:151-155.

Parkinson, J.A. and S.E. Allen. 1975. A wet oxidation procedure for the determination of $\mathrm{N}$ and mineral nutrients in biological materials. Commun. Soil Sci. Plant Anal. 6:1-11.

Picchioni, G.A., S. Miyamoto, and J.B. Storey. 1990. Salt effects on growth and ion uptake of pistachio rootstock seedlings. J. Amer. Soc. Hort. Sci. 115:647-653.

Rains, D.W. and E. Epstein. 1967. Sodium absorption by barley roots: Role of dual mechanisms of alkali cation transport. Plant Physiol. 42:314-318

Spiers, J.M. 1983. Influence of N, K, and Na concentration on growth and leaf element content of 'Tifblue' rabbiteye blueberry. HortScience 18:223-224.

Spiers, J.M. and J.H. Braswell. 1992. Soil-applied sulfur affects elemental leaf content and growth of 'Tifblue' rabbiteye blueberry. J. Amer. Soc. Hort. Sci. 117:230-233.

Suhayda, C.G., J.L. Giannini, D.P. Briskin, and M.C. Shannon. 1990. Electrostatic changes in Lycopersicon esculentum root plasma membrane resulting from salt stress. Plant Physiol. 93:471-478.

Texas Department of Health. 1990. Chemical analysis of public water systems. Stock no. 2-123. Texas Dept. of Health, Austin.

Van Steveninck, R.F.M., M.E. Van Steveninck, R. Stelzer, and A. Läuchli. 1982. Studies on the distribution of $\mathrm{Na}$ and $\mathrm{Cl}$ in two species of lupin (Lupinus luteus and Lupinus angustifolius) differing in salt tolerance. Physiol Plant. 56:465-473.

Wright, G.C., K.D. Patten, and M.C. Drew. 1992. Salinity and supplemental calcium influence growth of rabbiteye and southern highbush blueberry. J. Amer. Soc. Hort. Sci. 117:749-756.

Wright, G.C., K.D. Patten, and M.C. Drew. 1993. Gas exchange and chlorophyll content of 'Tifblue' rabbiteye and 'Sharpblue' southern highbush blueberry exposed to salinity and supplemental calcium. J. Amer. Soc. Hort. Sci. 118:456-463. 